\title{
UNCOMMON SIDE EFFECTS OF SUNITINIB THERAPY IN A PATIENT WITH METASTATIC RENAL CELL CANCER: CASE REPORT
}

\author{
Robert Šeparović ${ }^{1}$, Mirjana Pavlović ${ }^{1}$, Tajana Silovski $^{1}$, Hrvoje Silovski ${ }^{2}$ and Ana Tečić Vuger ${ }^{1}$ \\ ${ }^{1}$ Sestre milosrdnice University Hospital Centre, University Hospital for Tumors, \\ Department of Internist Oncology, Zagreb, Croatia; ${ }^{2}$ Zagreb University Hospital Centre, \\ Department of Gastrointestinal Surgery, Zagreb, Croatia
}

\begin{abstract}
SUMMARY - Sunitinib is an orally administered multikinase inhibitor. This therapy can provoke uncommon side effects such as pancytopenia, tumor lysis syndrome, cardiac disorders, thromboembolic incidents, intestinal perforation, pancreatitis, acute renal failure, etc. We report a case of a 63-year-old female admitted to the hospital due to abdominal pain, nausea, vomiting and elevated blood pressure. One month earlier, sunitinib therapy for metastatic renal cell carcinoma was initiated. During the first cycle of therapy, after three weeks of sunitinib $50 \mathrm{mg}$ daily, symptoms started and she stopped taking the drug. At admission, laboratory tests revealed elevated serum and urine amylase, $\mathrm{C}$-reactive protein, urea and creatinine, and lowered platelet and leukocyte counts and hemoglobin value. Urine test showed proteinuria, erythrocyturia, leukocyturia and granulated cylinder. The patient was diagnosed with acute pancreatitis grade III, acute renal failure grade II, pancytopenia and urinary infection, and was hospitalized for five days. She was treated symptomatically and with antibiotic therapy because of persistently elevated C-reactive protein and pathologic urinary sediment, which led to subjective and clinical improvement. Acute pancreatitis, renal insufficiency and pancytopenia are rarely described side effects of sunitinib therapy, and clear connection between these conditions and drug activity is not yet determined. Medical specialists who prescribe and treat patients with sunitinib should be aware of the possible occurrence of these conditions and perform regular checkups of sunitinib treated patients.
\end{abstract}

Key words: Sunitinib; Carcinoma, renal cell; Drug-related side effects and adverse reactions; Pancreatitis; Acute kidney injury; Pancytopenia

\section{Introduction}

Sunitinib is an orally administered multikinase inhibitor that targets several tyrosine kinase inhibitors implicated in tumor growth, pathologic angiogenesis, and metastatic progression ${ }^{1,2}$. According to registration studies, common side effects reported in at least

Correspondence to: Robert Šeparovic, $M D$, Sestre milosrdnice University Hospital Centre, University Hospital for Tumors, Department of Internist Oncology, Ilica 197, HR-10000 Zagreb, Croatia E-mail: robertseparov@gmail.com

Received March 23, 2016, accepted August 23, 2016
$20 \%$ of patients include hypertension, fatigue, gastrointestinal disorders (decreased appetite, diarrhea, stomatitis, nausea, dyspepsia, esophagitis), skin disorders, hematologic disorders (anemia, thrombocytopenia, granulocytopenia), hypothyroidism, etc. Uncommon side effects ( $>1: 1000-<1: 100$ cases $)$ include pancytopenia, tumor lysis syndrome, cardiac disorders, thromboembolic incidents, intestinal perforation, pancreatitis, Stevens-Johnson syndrome, acute renal failure and proteinuria $^{3-5}$. We report a case of few uncommon sunitinib therapy side effects in a patient with metastatic renal cell carcinoma (mRCC). 


\section{Case Report}

A 63-year-old woman with medical history of well regulated hypertension, adult renal polycystosis and chronic renal failure stage 3A (glomerular filtration rate (GFR) $47.7 \mathrm{~mL} / \mathrm{min}$ ) was admitted to the hospital due to abdominal pain and nausea, vomiting and elevated blood pressure (up to 180/130 $\mathrm{mm} \mathrm{Hg}$ ), which had started gradually one week before. The patient noticed that symptoms started three weeks after sunitinib therapy for $\mathrm{mRCC}$ had been initiated. In June 2010, the patient underwent radical right sided nephrectomy due to renal adenocarcinoma. In March 2012, lung metastases were verified by positron emission tomography-computed tomography. In May 2012, first line treatment for $\mathrm{mRCC}$ with sunitinib was initiated. During the first cycle of $50 \mathrm{mg}$ sunitinib daily, the symptoms started after three weeks, so she stopped taking the drug. On hospital admission, laboratory tests revealed elevated serum and urine amylase (138 and $1997 \mathrm{U} / \mathrm{L}), \mathrm{C}$-reactive protein (CRP, 90 $\mathrm{mg} / \mathrm{L})$, urea $(13.4 \mathrm{mmol} / \mathrm{L})$ and creatinine $(213$ $\mu \mathrm{mol} / \mathrm{L}$; GFR $28.2 \mathrm{~mL} / \mathrm{min})$, and lowered platelet $\left(39 \times 10^{9} / \mathrm{L}\right)$ and leukocyte $\left(2.56 \times 10^{9} / \mathrm{L}\right)$ counts and hemoglobin value $(100 \mathrm{~g} / \mathrm{L})$. Urine test showed proteinuria, erythrocyturia, leukocyturia and granulated cylinder. Abdominal ultrasound revealed bilateral pleural effusions, free fluid in lower abdomen, enlarged left kidney with canal system dilatation and gallbladder concrement of $3 \mathrm{~cm}$ in size without bile duct dilatation but the pancreas was not visualized due to meteorism. The patient was diagnosed with acute pancreatitis grade III, acute renal failure grade II (worsening of chronic kidney failure), pancytopenia and urinary infection (graduation according to Common Terminology Criteria for Adverse Events v. 4.03). She was treated symptomatically and, because of persistently elevated CRP and pathologic urine sediment, with antibiotic therapy (amoxicillin/clavulanic acid), which led to subjective and clinical improvement (decrease of serum and urine amylase and CRP, initial decrease of creatinine value). Antihypertensive therapy was also modified. The patient was discharged after five days and further checkups were provided by oncologist in outpatient care. After recovery, in October 2012, the patient started therapy with sorafenib, which she tolerated well.

\section{Discussion}

Acute pancreatitis, acute renal failure and pancytopenia, which were all found in our patient, are uncommon side effects of sunitinib therapy. In a phase III study conducted in 2007, Motzer et al. compared the efficacy of sunitinib (375 patients) versus interferon alfa (360 patients) for mRCC; increase in amylase and lipase level was recorded in $84(22.4 \%)$ patients in sunitinib arm (20.2\% of which were grade III and $4.8 \%$ grade IV); there were no cases of acute pancreatitis in that study ${ }^{3}$. To the best of our knowledge, only three cases of acute pancreatitis have been reported in the literature, i.e. one patient on combined tyrosine kinase therapy treated for non-small-cell lung carcinoma, one patient on combined therapy with sunitinib, gemcitabine and cisplatin treated for high-grade urothelial carcinoma, and one patient on combined radioimmunotherapy for hepatocellular carcinoma; none has been reported in patients receiving sunitinib for $\mathrm{mRCC}{ }^{6-8}$. Considering renal toxicity, according to the study by Motzer et al., increased creatinine values were recorded in 66 (17.6\%, of which only one grade III case) patients receiving sunitinib for $\mathrm{mRCC}^{3}$. There are few retrospective studies conducted in patients with renal impairment at the start of sunitinib therapy, suggesting that sunitinib is safe in that population (metabolized primarily in the liver) but often causes creatinine level increase and demands dose adjustment due to the higher incidence of non-renal toxicity and hypertension ${ }^{9-12}$. There are few case reports on acute renal failure in patients receiving sunitinib ${ }^{13,14}$. A1though our patient had a history of chronic renal insufficiency, during sunitinib therapy she experienced worsening of her usually stable disease (acute-onchronic renal failure) and we could not determine with certainty if worsening of her renal function was a consequence of dehydration due to vomiting or an effect of sunitinib. According to registration studies, anemia, leukocytopenia and thrombocytopenia are common adverse events associated with sunitinib therapy; however, to the best of our knowledge, pancytopenia has not yet been reported in postmarketing experience ${ }^{3,15}$.

\section{Conclusion}

Acute pancreatitis, renal insufficiency and pancytopenia are rarely described side effects of sunitinib ther- 
apy and clear connection between these conditions and drug activity has not yet been determined. Medical specialists who prescribe and treat patients with sunitinib should be aware of the possible occurrence of these conditions and perform regular checkups of treated patients.

\section{References}

1. Abrams TJ, Lee LB, Murray LJ, Pryer NK, Cherrington JM. SU11248 inhibits KIT and platelet-derived growth factor receptor beta in preclinical models of human small cell lung cancer. Mol Cancer Ther. 2003;2:471-8.

2. O'Farrell AM, Abrams TJ, Yuen HA, et al. SU11248 is novel FLT3 tyrosine kinase inhibitor with potent activity in vitro and in vivo. Blood. 2003;101:3597-605. doi: https://doi.org/10.1182/blood-2002-07-2307

3. Motzer RJ, Hutson TE, Tomczak P, Michaelson MD, Bukowski RM, et al. Sunitinib versus interferon alfa in metastatic renal-cell carcinoma. N Engl J Med. 2007 Jan 11;356(2):115-24. doi: https://www.nejm.org/doi/full/10.1056/NEJMoa065044

4. Raymond E, Dahan L, Raoul JL, Bang YL, Borbath I, et al. Sunitinib malate for the treatment of pancreatic neuroendocrine tumors. N Engl J Med. 2011 Feb 10;364(6):501-13. doi: https://www.nejm.org/doi/full/10.1056/NEJMoa1003825

5. Demetri GD, van Oosterom AT, Garrett CR, Blackstein ME, Shah $\mathrm{MH}$, et al. Efficacy and safety of sunitinib in patients with advanced gastrointestinal stromal tumor after failure of imatinib: a randomized controlled trial. Lancet. 2006 Oct 14;368 (9544)1329-38 doi: https://doi.org/10.1016/S0140-6736(06)69446-4

6. Ruinemans GM, Balemans C, Mattijssen V, Wiersma-van Tilburg AJ, Smit HJ. Fatal necrotizing pancreatitis during combined treatment with erlotinib and sunitinb. Lung Cancer. 2010 Dec;70(3):364-5.

doi: https://doi.org/10.1016/j.lungcan.2010.08.004
7. Vogelzang NJ. Antiangiogenic agents, chemotherapy and the treatment of metastatic transitional cell carcinoma. J Clin Oncol. 2013 Feb 20;31(6):670-5. doi: http://ascopubs.org/ doi/10.1200/JCO.2012.44.4349

8. Chi KH, Liao CS, Chang CC, Ko HL, Tsang YW, Yang KC, et al. Angiogenic blockade and radiotherapy in hepatocellular carcinoma. Int J Radiat Oncol Biol Phys. 2010 Sep 1;78(1): 188-93. doi: https://doi.org/10.1016/j.ijrobp.2009.07.1725

9. Gupta S, Parsa V, Heilbrun LK, Smith DW, Dickow B, Heath $\mathrm{E}$, et al. Safety and efficacy of molecularly targeted agents in patients with metastatic kidney cancer with renal dysfunction. Anticancer Drugs. 2011 Sep;22(8):794-800. doi: https://doi.org/10.1097/CAD.0b013e328346af0d

10. Khan G, Golshayan A, Elson P,Wood L, Garcia J, Bukowski R, et al. Sunitinib and sorafenib in metastatic renal cell carcinoma patients with renal insufficiency. Ann Oncol. 2010 Aug;21(8): 1618-22. doi: https://doi.org/10.1093/annonc/mdp603

11. Bello Carlo BH-Z, Patyna S, Kang P, Klamerus K. A phase I mass-balance study to evaluate the metabolism and excretion of [14C]-sunitinib (SU11248) in healthy male subjects. Annual Meeting of the American Association for Cancer Research 2007; Los Angeles, California.

12. Zhu X, Stergiopolus K, Wu S. Risk of hypertension and renal dysfunction with an angiogenesis inhibitor sunitinib: systematic review and meta-analysis. Acta Oncol. 2009;48(1):9-17. doi: https://doi.org/10.1080/02841860802314720

13. Lim TJ, Lee JH, Chang SG, Lee CH, Min GE, et al. Lifethreatening complications associated with the tyrosine kinase inhibitor sunitinib malate. Urol Int. 2010;85(4):475-8. doi: https://doi.org/10.1159/000321175

14. Kawsar HI, Bansal S, Myles JL. Acute renal failure: a rare side effect of sunitinib therapy. Med Oncol 2012 Dec;29(5):3594-6. doi: https://doi.org/10.1007/s12032-012-0272-2

15. Funakoshi T, Latif A, Galsky MD. Risk of hematologic toxicities in cancer patients treated with sunitinib: a systematic review and meta-analysis. Cancer Treat Rev. 2013 Nov;39(7): 818-30. doi: https://doi.org/10.1016/j.ctrv.2013.01.004 


\title{
Sažetak \\ RIJETKE NUSPOJAVE TERAPIJE SUNITINIBOM
U BOLESNICE S METASTATSKIM KARCINOMOM BUBREGA: PRIKAZ SLUČAJA
}

\author{
R. Šeparović, M. Pavlović, T. Silovski, H. Silovski i A. Tečić Vuger
}

Sunitinib je oralni multikinazni inhibitor. Liječenje može izazvati pojavu rijetkih nuspojava kao što su pancitopenija, sindrom lize tumora, srčani poremećaji, tromboembolijski incidenti, perforacija crijeva, pankreatitis, akutno zatajenje bubrega itd. Ovdje prikazujemo slučaj 63-godišnje bolesnice hospitalizirane zbog bolova u trbuhu, mučnine, povraćanja i povišenog krvnog tlaka. Mjesec dana ranije je započela liječenje sunitinibom zbog metastatskog karcinoma bubrega. U bolesnice su se tijekom prvog ciklusa liječenja, nakon tri tjedna uzimanja $50 \mathrm{mg}$ sunitiniba na dan, pojavili navedeni simptomi zbog čega je bolesnica prekinula uzimati lijek. Pri prijmu u bolnicu su laboratorijski nalazi pokazali povišene vrijednosti serumskih i mokraćnih amilaza, C-reaktivnog proteina, ureje i kreatinina, sniženi broj trombocita i leukocita te sniženu vrijednost hemoglobina. Postavljena je dijagnoza akutnog pankreatitisa gr. III., akutnog bubrežnog zatajenja gr. II, pancitopenije i urinarne infekcije te je bolesnica hospitalizirana tijekom pet dana. Liječena je simptomatski te antibiotikom zbog povišene vrijednosti C-reaktivnog proteina i patološkog sedimenta mokraće, što je dovelo do subjektivnog i kliničkog poboljšanja stanja. Akutni pankreatitis, bubrežno zatajenje i pancitopenija su rijetko opisivane nuspojave primjene sunitiniba i jasna veza između tih stanja i aktivnosti lijeka još nije utvrđena. Specijalisti koji propisuju i liječe bolesnike sunitinibom trebali bi biti svjesni mogućnosti pojave ovih stanja i provoditi redovite kontrole u bolesnika liječenih ovim lijekom.

Ključne riječi: Sunitinib; Karcinom bubrežnih stanica; Uzimanje lijekova, nuspojave i štetna djelovanja; Pankreatitis; Akutna bubrežna trauma; Pancitopenija 